\title{
PENGARUH MANAJEMEN PEMBERIAN PAKAN TERHADAP PEMANFAATAN BIOFLOK UNTUK PERTUMBUHAN IKAN BANDENG
}

\author{
Usman $^{*}$, Neltje Nobertine Palinggi*), Enang Harris**), Dedi Jusadi**), dan \\ Eddy Supriyono*) \\ *) Balai Riset Perikanan Budidaya Air Payau \\ Jl. Makmur Dg. Sitakka No. 129, Maros 90512, Sulawesi Selatan \\ E-mail: litkanta@indosat.net.id \\ **) Fakultas Perikanan dan IImu Kelautan, Institut Pertanian Bogor \\ J. Raya Darmaga, Kampus IPB Darmaga, Bogor 16680
}

(Naskah diterima: 1 Agustus 2011; Disetujui publikasi: 28 Oktober 2011)

\begin{abstract}
ABSTRAK
Upaya konversi limbah budidaya ikan menjadi bioflok mulai banyak dilakukan oleh pembudidaya untuk memperbaiki kualitas air dan menekan biaya pakan. Penelitian ini bertujuan untuk meningkatkan pemanfaatan bioflok sebagai makanan ikan bandeng melalui pengaturan dosis pemberian pakan. Perlakuan yang dicobakan adalah ikan uji dipelihara dengan: (A) bioflok tanpa diberi pemberian pakan buatan, (B) bioflok + pakan buatan sebanyak $2,5 \%$ per hari, (C) bioflok + pakan buatan sebanyak $5 \%$ perhari, (D) pemberian pakan buatan sebanyak 5\% hari tanpa bioflok. Hasil penelitian menunjukkan bahwa ikan bandeng ukuran awal rata- rata 1,6 g yang hanya diberi bioflok dapat tumbuh dengan laju pertumbuhan $1,82 \%$ hari, namun laju pertumbuhan ini masih lebih rendah dibandingkan yang diberi pakan buatan $5 \%$ hari yaitu $2,01 \%$ hari. Tanpa memperhitungkan jumlah pemberian molase, ikan yang diberi pakan buatan sebanyak 2,5\% hari dalam media bioflok, dapat meningkatkan efisiensi pakan sebanyak 58,5\% dan efisiensi pemanfaatan protein sebanyak $59,2 \%$ Kandungan TAN, nitrit dan oksigen terlarut dalam media budidaya cukup baik bagi pertumbuhan ikan bandeng.
\end{abstract}

KATA KUNCI: manajemen pakan, efisiensi, pemanfaatan, bioflok

ABSTRACT: The effect of feeding management on the utilization of biofloc by milkfish. By: Usman, Neltje Nobertine Palinggi, Enang Harris, Dedi Jusadi, and Eddy Supriyono

The effort to recycle aquaculture waste to produce biofloc has been practiced by many aquaculturist to improve water quality and reduce feed cost. This research was conducted to increase the utilization of biofloc by milkfish as food through feeding management (feeding dose). The treatmens consisted of test fish (average initial body weight of $1.6 \mathrm{~g} / \mathrm{ind}$ ) reared in media with (A) biofloc without artificial feed, (B) biofloc + artificial feed of 2,5\% bw/day, (C) biofloc + artificial feed of $5 \%$ bw/day, (D) artificial feed of $5 \%$ bw/day without biofloc. The results showed that the milkfish which were given only biofloc had specific growth rate of 1.82\%/day, however this growth rate was lower than the growth rate of fish fed with artificial feed of $5 \%$ bw/day $(2.01 \% /$ day). Without calculating the addition of molase, the fish fed with artificial feed of $2.5 \%$ bw/day + biofloc coulhad an increase of feed efficiency up to 58.5\% and protein efficiency ratio of 59.2\%. Levels of TAN, nitrite and dissolved oxygen in the media culture were suitable for milk fish growth.

KEYWORDS: feeding management, efficiency, utilization, biofloc 


\section{PENDAHULUAN}

Pakan ikan umumnya mengandung protein cukup tinggi, karena protein selain digunakan untuk pertumbuhan juga digunakan sebagai sumber energi utama oleh ikan (Wilson, 2002). Oleh karena itu, ikan banyak mengeluarkan limbah $\mathrm{N}$, utamanya amoniak $\left(\mathrm{NH}_{3}\right)$ sebagai hasil perombakan protein dan deaminasi asam amino untuk keperluan metabolismenya (Halver \& Hardy, 2002). Hal ini menyebabkan efisiensi protein pakan menjadi rendah dan pengeluaran limbah $\mathrm{N}$ anorganik, utamanya amoniak $\left(\mathrm{NH}_{3}\right)$ yang bersifat toksik menjadi tinggi. Selain itu, terdapat limbah N organik yang berasal dari sisa pakan yang tidak termakan dan feses yang akan didekomposisi oleh mikroba dalam kolom air dan dasar perairan sehingga dapat peningkatan total ammonianitrogen (TAN $=\mathrm{NH}_{3}+\mathrm{NH}_{4}$ ) dan nitrit karena terjadinya transformasi nitrogen dan keduanya berbahaya untuk ikan sekalipun pada konsentrasi yang rendah (Schneider et al., 2005).

Pada teknologi bioflok, ammonia dan limbah organik nitrogen akan dikonversi menjadi biomassa bakteri heterotrof, jika terjadi keseimbangan antara karbon organik dan nitrogen (Schneider et al., 2005). TAN yang berasal dari dekomposisi pakan yang tidak termakan dan feses serta dari ekskresi ikan akan dimanfaatkan oleh bakteri pada flok. Untuk menjaga keseimbangan nitrogen dan karbon dalam media budidaya ikan intensif agar bakteri heterotrof dapat tumbuh maksimal, perlu ditambahkan C- organik dalam media budidaya dengan pergantian air seminimal mungkin. Pada kepadatan bakteri heterotrof yang cukup tinggi dalam media akan memicu terbentuknya bioflok. Bioflok ini merupakan campuran heterogen dari mikroba (plankton, fungi, protozoa, ciliata, nematoda), partikel, koloid, polimer organik, kation yang saling berintegrasi cukup baik dalam air untuk tetap bertahan dari agitasi (goncangan) air yang moderat (Jorand et al., 1995). Terbentuknya bioflok akan menurunkan limbah nitrogen dalam media budidaya (Avnimelech, 1999). Selain itu, bioflok yang terbentuk ini mengandung nutrisi seperti protein (19-58\%), lemak (2-39\%), karbohidrat ( $27 \% 59 \%$, dan abu ( $2 \%$ 17\% yang cukup bagus bagi ikan/ udang budidaya (Verstraete et al., 2008; Crab et al., 2009). Oleh karena itu, penumbuhan flok mikroba heterotrofik ini merupakan suatu solusi untuk menekan beban limbah budidaya ikan dan meningkatkan pemanfaatan protein pakan.

Beberapa penelitian telah dilaporkan bahwa bioflok dapat dimanfaatkan sebagai makanan alami oleh beberapa spesies ikan seperti nila (Avnimelech, 2007), udang vaname (Burford et al., 2004), dan udang galah (Crab et al., 2009). Pada budidya ikan nila merah secara intensif, 50\%kebutuhan protein dapat disuplai dari bioflok yang ditumbuhkan dalam media budidaya tersebut. Pada budidaya udang Litopenaeus vannamei, bioflok dapat menggantikan peran pakan buatan hingga 30\% (Ekasari, 2008). Sementara Crab et al. (2009) melaporkan bahwa bioflok dapat digunakan sebagai makanan alami dalam pemeliharaan post larva udang galah, Macrobrachium rosenbergii.

Ikan bandeng merupakan salah satu jenis ikan yang memiliki preferensi makanan yang relatif beragam yaitu memakan zooplankton, diatom, bentos kecil, alga filamen, alga mat, dan detritus (Bagarinao, 1994). Struktur tapis insang ikan bandeng yang panjang- panjang dan rapat memiliki fungsi sebagai penyaring mikroorganisme air (seperti plankton) dan juga memiliki epibrancheal organ yang berfungsi sebagai alat untuk memadatkan material yang dimakan sebelum ditelan (Huisman 1987). Namun penelitian sebelumnya menunjukkan bahwa, ikan bandeng yang dipelihara dalam media yang ditumbuhkan bioflok tanpa pemberian pakan buatan, tampaknya memiliki pertumbuhan yang relatif masih lambat, sehingga diduga ikan bandeng ini tidak dapat tumbuh secara maksimal hanya dengan mengandalkan bioflok sebagai makanan tunggal (Usman et al., 2011). Sehubungan dengan hal tersebut, maka telah dilakukan penelitian tentang penumbuhan dan pemanfaatan bioflok sebagai makanan pada budidaya ikan bandeng dengan pengaturan dosis pemberian pakan buatan dengan harapan untuk meningkatkan efisiensi protein dan pakan.

\section{BAHAN DAN METODE}

\section{Wadah Percobaan}

Wadah penumbuhan bioflok berupa 12 tangki beton berukuran 2,0 $\mathrm{m} \times 1,50 \mathrm{~m} \times 1,2 \mathrm{~m}$ yang akan diisi air bersalinitas sekitar $25 \mathrm{ppt}$ masing- masing sebanyak 1,5 ton. Setiap tangki dipasang jaring keramba (ukuran mata jaring sekitar $72 \mathrm{~mm}$, agar pakan pelet tidak keluar) 
yang berukuran $0,75 \mathrm{~m} \times 0,75 \mathrm{~m} \times 1,0 \mathrm{~m}$. Jarak dasar jaring dengan dasar bak masih tersisa sekitar $10 \mathrm{~cm}$ sehingga ikan bisa bebas bergerak di bawah jaring.

\section{Pemeliharaan Ikan}

Ikan bandeng berukuran rata- rata $75 \mathrm{~g}$ sebanyak 20 ekor (total biomassa sekitar 1500 g) dimasukkan ke dalam jaring keramba yang ada dalam setiap bak beton tersebut. Ikan dalam keramba tersebut diberi pakan komersil dengan kadar protein sekitar $26 \%$ sebanyak $3 \% 4 \%$ dari biomassa per hari pada pagi, siang, dan sore hari. Ikan dalam keramba tersebut berfungsi untuk menghasilkan limbah nitrogen yang akan digunakan untuk menumbuhkan bioflok. Untuk menumbuhkan bioflok dalam media budidaya tersebut, maka setelah pemberian pakan pada pagi dan sore hari, ke dalam media pemeliharaan tersebut diberi C- organik (molase) sehingga tercipta kondisi $\mathrm{C} / \mathrm{N}$ rasio sekitar 15 dengan metode perhitungan seperti yang dilaporkan oleh Usman et al. (2010). Pada awal pemeliharaan, juga diinokulasi bakteri komersil sebanyak $1 \times 10^{6}$ $\mathrm{cfu} / \mathrm{mL}$. Sistem aerasi diatur sedemikian rupa sehingga bahan organik dapat tersuspensi terus dalam media pemeliharaan dan kadar oksigen terlarut $>3 \mathrm{mg} / \mathrm{L}$.

Setelah bioflok tumbuh dalam media pemeliharaan, pada bagian luar keramba tersebut ditebar ikan bandeng ukuran bobot rata- rata 1,6 g sebanyak 100 ekor per bak. Ikan bandeng di luar jaring keramba tersebut diberi perlakuan sebagai berikut:

(A) Bioflok tanpa diberi pakan buatan

(B) Bioflok + pakan buatan sebanyak 2,5\%per hari, pada pagi, siang, dan sore hari

(C) Bioflok + pakan buatan sebanyak 5\%per hari, pada pagi, siang, dan sore hari

(D) Pakan buatan sebanyak 5\%per hari tanpa bioflok, dengan pergantian air harian sekitar 30\%(metode konvensional, kontrol)

Pakan uji yang diberikan pada ikan bandeng yang berada di luar jaring tersebut adalah pakan komersil dengan kandungan protein $32,6 \%$ lemak $6,2 \%$ serat kasar 3,6\% abu $11,4 \%$ dan energi 18,1 MJ/ kg.

\section{Peubah yang Diamati}

Peubah yang diamati meliputi: TAN, nitrit, nitrat, total suspended solid (TSS), volatile suspended solid (VSS), dan floc volume indeks (FVI) diukur berdasarkan APHA (1995). Oksigen terlarut, suhu, dan $\mathrm{pH}$ diukur secara insitu menggunakan DO- meter dan $\mathrm{pH}$ - meter. Total bakteri heterotrof dalam media pemeliharaan diamati setiap 6 hari dan dihitung berdasarkan APHA (1995). Analisis proksimat bioflok dilakukan berdasarkan metode AOAC International (1999): bahan kering (DM) dikeringkan dengan oven pada suhu $105^{\circ} \mathrm{C}$ selama 16 jam, serat kasar dengan ekstraksi ether, abu dengan pembakaran dalam muffle furnace pada suhu $550^{\circ} \mathrm{C}$ selama $24 \mathrm{~h}$ dan protein kasar dianalisis dengan micro-Kjeldahl, lemak dideterminasi secara gravimetric dengan ekstraksi chloroform : methanol pada sampel.

Laju pertumbuhan spesifik (SGR) ikan berdasarkan formulasi berikut (Schulz et al., 2005):

$$
\text { SGR (\%per hari) }=\frac{\left(\ln W_{e}-\operatorname{Ln~W}_{s}\right)}{d} \times 100
$$

di mana:

In adalah logaritma alamiah, $\mathrm{W}_{\mathrm{e}}$ dan $\mathrm{W}_{\mathrm{s}}$ berturutturut adalah bobot ikan pada akhir dan awal penelitian, dan d adalah jumlah hari pemeliharaan. In is natural logarithm, $W_{e}$ and $W_{s}$ consecutively are fish body weight at the beginning and the end of rearing period, and $d$ is the rearing period

Efisiensi pakan $=$ Pertambahan bobot biomassa (bobot basah) / Bobot konsumsi pakan (bobot kering) (Takeuchi, 1988) (Feed efficiency = Weight gain (wet weight) / Consumed feed weight (dry weight)

Rasio efisiensi protein, PER = Pertambahan bobot ikan (g) / Jumlah protein yang dimakan (g) (Hardy, 1989) (Protein efficiency ratio $=$ Weight gain of fish $(\mathrm{g}) /$ Total consumed protein)

Sintasan ikan, SR $(\%)=$ (Jumlah ikan akhir penelitian / Jumlah ikan awal penelitian) $x 100$ (Survival rate $=$ Number of survived fish at the end of / Number of fish at the beginning of the experiment)

Hasil pengamatan karakteristik pertumbuhan ikan dianalisis ragam, sementara data kualitas air dianalisis secara deskriptif.

\section{HASIL DAN BAHASAN}

\section{Hewan Uji}

Pemeliharaan ikan bandeng di dalam jaring keramba (penyuplai utama total ammonia nitrogen, TAN) pada bak penumbuhan bioflok 
berlangsung selama 60 hari, dan pemeliharaan ikan di luar jaring yang diberi perlakuan perbedaan dosis pakan berlangsung selama 45 hari.

\section{Karakteristik Pertumbuhan Ikan di Dalam Jaring}

Karakteristik pertumbuhan ikan di dalam jaring yang diberi pakan pelet sebagai penyuplai utama TAN untuk penumbuhan bioflok dalam media budidaya disajikan pada Tabel 1.

Pada Tabel 1 terlihat bahwa laju pertumbuhan bobot harian ikan dalam jaring ratarata sekitar $1,1 \%$ hari, dan tidak berbeda nyata $(P>0,05)$ di antara semua perlakuan. Demikian juga sintasan ikan relatif sama diantara perlakuan $(P>0,05)$. Hal ini mengindikasikan bahwa ikan bandeng yang dipelihara dengan teknologi bioflok (perlakuan A, B, dan C) memiliki pertumbuhan yang relatif sama dengan ikan bandeng yang dipelihara secara konvensional (perlakuan $\mathrm{D}$, pergantian air sekitar 30\% per hari (kontrol)). Dalam hal pemanfaatan pakan, tampak bahwa efisiensi pakan dan efisiensi protein juga tidak berbeda nyata diantara perlakuan $(P>0,05)$. Hal ini menunjukkan bahwa ikan bandeng di dalam jaring yang dipelihara dengan teknologi bioflok relatif hanya memanfaatkan pakan buatan yang diberikan untuk pertumbuhannya. Sementara bioflok yang tumbuh di dalam media pemeliharaan tidak dimanfaatkan dengan baik untuk pertumbuhannya.

\section{Karakteristik Pertumbuhan Ikan di Luar Jaring}

Karakteristik pertumbuhan ikan bandeng di luar jaring (yang diberi perlakuan perbedaan dosis pakan buatan), disajikan pada Tabel 2 . Pada tabel tersebut terlihat bahwa sintasan ikan relatif sama diantara perlakuan $(P>0,05)$, meskipun ada sedikit kecenderungan sintasan ikan meningkat dengan meningkatnya dosis pemberian pakan. Laju pertumbuhan ikan menunjukkan adanya perbedaan yang nyata $(\mathrm{P}<0,05)$ di antara perlakuan. Ikan yang tidak diberi pakan buatan masih dapat mengalami

Tabel 1. Karakteristik pertumbuhan ikan bandeng yang diberi pakan pelet dalam jaring selama 60 hari pemeliharaan

Table 1. Characteristic of milkfish growth fed with pellet in biofloc media for 60 days rearing periode

\begin{tabular}{|c|c|c|c|c|}
\hline \multirow[b]{2}{*}{$\begin{array}{l}\text { Peubah } \\
\text { Variable }\end{array}$} & \multicolumn{4}{|c|}{ Perlakuan (Treatments) } \\
\hline & $\begin{array}{c}\text { A. } \\
\text { Bioflok } \\
\text { Biofloc }\end{array}$ & $\begin{array}{c}\text { B. } \\
\text { Bioflok }+2.5 \% \\
\text { pakan (Biofloc } \\
+ \text { feed } 2.5 \%)\end{array}$ & $\begin{array}{c}\text { C. } \\
\text { Bioflok +5\% } \\
\text { pakan (Biofloc } \\
+ \text { feed 5\%) }\end{array}$ & $\begin{array}{c}\text { D. } \\
\text { 5\% pakan } \\
\text { Feed 5\% }\end{array}$ \\
\hline $\begin{array}{l}\text { Bobot awal } \\
\text { Initial weight }(\mathrm{g})\end{array}$ & 75.3 & 75.7 & 75.7 & 75.5 \\
\hline $\begin{array}{l}\text { Bobot akhir } \\
\text { Final weight (g) }\end{array}$ & 142.7 & 143.1 & 143.6 & 146.1 \\
\hline $\begin{array}{l}\text { Laju pertumbuhan spesifik ( } \% \text { hari) } \\
\text { Specific growth rate (\%/day) }\end{array}$ & $1.07 \pm 0.04^{\mathrm{a}}$ & $1.06 \pm 0.04^{\mathrm{a}}$ & $1.07 \pm 0.02^{\mathrm{a}}$ & $1.1 \pm 0.03^{\mathrm{a}}$ \\
\hline $\begin{array}{l}\text { Sintasan } \\
\text { Survival rate }(\%)\end{array}$ & $96.7 \pm 5.8^{\mathrm{a}}$ & $96.7 \pm 2.9^{a}$ & $100 \pm 0^{\mathrm{a}}$ & $98.3 \pm 2.9^{a}$ \\
\hline $\begin{array}{l}\text { Efisiensi pakan } \\
\text { Feed efficiency }\end{array}$ & $0.43 \pm 0.02^{a}$ & $0.42 \pm 0.01^{\mathrm{a}}$ & $0.44 \pm 0.01^{\mathrm{a}}$ & $0.43 \pm 0.01^{\mathrm{a}}$ \\
\hline $\begin{array}{l}\text { Protein efisiensi rasio } \\
\text { Protein efficiency ratio }\end{array}$ & $1.72 \pm 0.08^{a}$ & $1.69 \pm 0.03^{\mathrm{a}}$ & $1.77 \pm 0.05^{\mathrm{a}}$ & $1.72 \pm 0.03^{a}$ \\
\hline
\end{tabular}

Nilai tengah dalam baris yang sama diikuti superscript yang sama menunjukkan tidak berbeda nyata $(P>0,05)$ (Means in the same row followed by the same superscript are not significantly different) $(P>0.05)$ 
Tabel 2. Karakteristik pertumbuhan ikan bandeng di luar jaring selama 45 hari pemeliharaan Table 2. Characteristic of milkfish growth fed only with biofloc for 45 days rearing periode

\begin{tabular}{|c|c|c|c|c|}
\hline \multirow[b]{2}{*}{$\begin{array}{l}\text { Peubah } \\
\text { Variable }\end{array}$} & \multicolumn{4}{|c|}{ Perlakuan (Treatments) } \\
\hline & $\begin{array}{c}\text { A. } \\
\text { Bioflok } \\
\text { Biofloc }\end{array}$ & $\begin{array}{c}\text { B. } \\
\text { Bioflok }+2.5 \% \\
\text { pakan (Biofloc } \\
+ \text { feed } 2.5 \%)\end{array}$ & $\begin{array}{c}\text { C. } \\
\text { Bioflok +5\% } \\
\text { pakan (Biofloc } \\
+ \text { feed 5\%) }\end{array}$ & $\begin{array}{c}\text { D. } \\
\text { 5\% pakan } \\
\text { Feed 5\% }\end{array}$ \\
\hline $\begin{array}{l}\text { Bobot awal } \\
\text { Initial weight }(\mathrm{g})\end{array}$ & 1.64 & 1.68 & 1.65 & 1.66 \\
\hline $\begin{array}{l}\text { Bobot akhir } \\
\text { Final weight }(\mathrm{g})\end{array}$ & 3.71 & 3.86 & 4.04 & 4.09 \\
\hline $\begin{array}{l}\text { Laju pertumbuhan spesifik ( } \% \text { hari) } \\
\text { Specific growth rate (\%/day) }\end{array}$ & $1.82 \pm 0.10^{\mathrm{a}}$ & $1.87 \pm 0.05^{\mathrm{ab}}$ & $1.99 \pm 0.07^{b}$ & $2.01 \pm 0.09^{b}$ \\
\hline $\begin{array}{l}\text { Sintasan } \\
\text { Survival rate }(\%)\end{array}$ & $63.7 \pm 11.2^{\mathrm{a}}$ & $64.0 \pm 8.7^{a}$ & $72.3 \pm 9.1^{\mathrm{a}}$ & $72.0 \pm 11.1^{\mathrm{a}}$ \\
\hline $\begin{array}{l}\text { Efisiensi pakan } \\
\text { Feed efficiency }\end{array}$ & - & $0.84 \pm 0.10^{\mathrm{a}}$ & $0.51 \pm 0.07^{b}$ & $0.53 \pm 0.08^{b}$ \\
\hline $\begin{array}{l}\text { Protein efisiensi rasio } \\
\text { Protein efficiency ratio }\end{array}$ & - & $2.58 \pm 0.30^{\mathrm{a}}$ & $1.56 \pm 0.22^{\mathrm{b}}$ & $1.62 \pm 0.26^{b}$ \\
\hline
\end{tabular}

Nilai tengah dalam baris yang sama diikuti superscript yang sama menunjukkan tidak berbeda nyata $(P>0,05)$ (Means in the same row followed by the same superscript are not significantly different) $(P>0.05)$

laju pertumbuhan spesifik sekitar $1,82 \%$ hari dengan memanfaatkan bioflok yang tumbuh dalam media budidaya. Ikan bandeng yang diberi pakan buatan sebanyak 2,5\% per hari mengalami laju pertumbuhan sekitar 1,87\% hari. Ikan bandeng yang diberi pakan buatan sebanyak $5 \%$ per hari pada media yang ditumbuhi bioflok mengalami laju pertumbuhan sebanyak 1,99\% hari dan relatif sama dengan laju pertumbuhan ikan pada media yang tidak ditumbuhi bioflok tetapi diberi pakan buatan $5 \%$ per hari (konvensional) yaitu 2,01\% hari. Hal ini menunjukkan bahwa, pada dasarnya ikan bandeng ini masih lebih menyukai pakan buatan tersebut daripada bioflok, sehingga pakan buatan lebih mendominasi perannya dalam pertumbuhan ikan bandeng, khususnya pada ikan yang diberi pakan buatan $5 \%$ hari. Hal ini juga tercermin pada ikan yang diberi pakan buatan sebanyak 2,5\% per hari yang hanya mengalami pertumbuhan sekitar $1,87 \%$ per hari.

Pemanfaatan pakan yang tercermin pada tingkat efisiensi pakan dan efisiensi protein menunjukkan adanya perbedaan nyata $(P<0,05)$ antara ikan yang diberi pakan buatan dosis 2,5\%dan 5\%perhari. Semakin meningkat dosis pemberian pakan buatan, efisiensi pakan dan efisiensi protein cenderung menurun. Hal ini menunjukkan bahwa bioflok masih dapat digunakan oleh ikan uji ini untuk pertumbuhannya pada saat diberi dosis pakan buatan yang tidak terlalu tinggi. Pada ikan yang hanya diberi pakan sekitar 2,5\% per hari memiliki efisiensi pakan cukup tinggi yaitu 0,84 dan rasio efisiensi protein sekitar 2,58 yang lebih tinggi dibanding pada ikan yang diberi pakan $5 \%$ per hari. Ikan yang diberi pakan buatan $5 \%$ per hari pada media yang ditumbuhi bioflok memiliki efisiensi pakan dan rasio efisiensi protein yang relatif sama dengan ikan pada media pemeliharaan konvensional (perlakuan D). Hal ini menunjukkan bahwa dengan pemberian pakan buatan $5 \%$ per hari, pemanfaatan bioflok tidak optimum. Tanpa memperhitungkan jumlah pemberian molase, ikan yang dipelihara dengan pemberian pakan sebanyak $2,5 \%$ per hari dengan teknologi bioflok, terjadi peningkatan efisiensi pakan sebanyak $58,5 \%$ dan efisiensi pemanfaatan protein sebanyak $59,2 \%$ dibandingkan dengan ikan yang hanya dipelihara secara konvesional dengan pemberian pakan buatan 5\%per hari. 


\section{Kualitas Air}

\section{Total Amoniak Nitrogen (TAN)}

Kandungan TAN dalam media budidaya cenderung meningkat hingga sekitar $0,9 \mathrm{mg} / \mathrm{L}$ pada hari ke- 9 pemeliharaan, kemudian menurun dan berfluktuasi kecil (Gambar 1). Kandungan TAN dalam media penumbuhan bioflok relatif tidak beda jauh dengan kandungan TAN dalam media budidaya ikan bandeng yang mengalami pergantian air sebanyak $30 \%$ hari. Hal ini menunjukkan bahwa kandungan TAN dalam media budidaya ikan bandeng dengan teknologi bioflok ini relatif dapat terkontrol dengan baik melalui assimilasi populasi mikroba heterotrof yang kemudian membentuk bioflok. Bioflok ini mulai terbentuk dengan baik sekitar hari ke-10, sehingga ikan uji yang berukuran sekitar 1,6 g tersebut ditebar pada hari ke- 15 dalam bak (di luar jaring).

\section{Nitrit}

Kandungan nitrit dalam media budidaya juga cenderung dapat terkontrol dengan baik selama pemeliharaan hewan uji (Gambar 2). Kandungan nitrit tertinggi terjadi pada hari ke- 51 yaitu sekitar 0,19 mg/ L. Dinamika kandungan nitrit dalam media budidaya dengan teknologi bioflok masih relatif sama dengan kandungan nitrit dalam media budidaya secara konvensional (kontrol). Kandungan nitrit selama penelitian ini masih relatif aman bagi kehidupan ikan bandeng. Kadar nitrit yang aman bagi pertumbuhan ikan bandeng adalah kurang dari $0,30 \mathrm{mg} / \mathrm{L}$ (Ahmad et al., 1993). Kandungan nitrit yang relatif terkontrol ini dapat terjadi karena 2 kemungkinan yaitu: (i) TAN yang terbentuk khususnya dari ekskresi ikan budidaya secara cepat diasimilasi oleh bakteri heterotrof, dan (ii) proses nitrifikasi tahap kedua yaitu proses oksidasi nitrit menjadi nitrat oleh bakteri nitrite oxidizing bacteria (NOB) seperti Nitrobakter, Nitrococcus, Nitrospira, dan Nitrospina berjalan lancar.

\section{Nitrat}

Kandungan nitrat dalam media budidaya dengan teknologi bioflok mengalami peningkatan yang cukup tinggi dibandingkan dengan dalam media budidaya secara konvensional (kontrol) dengan meningkatnya periode pemeliharaan (Gambar 3). Terjadinya peningkatan kandungan nitrat dalam media budidaya ini menunjukkan aktivitas oksidasi nitrit menjadi nitrat oleh nitrite oxidizing bacteria berjalan dengan baik. Laju pemanfaatan nitrat oleh mikroorganisme (plankton dan bakteri) tidak secepat laju pembentukan nitrat, sehingga terjadi peningkatan nitrat secara perlahan seiring dengan bertambahnya periode pemeliharaan. Meskipun Montoya \& Velasco (2000) juga melaporkan bahwa selain fitoplankton, beberapa jenis mikroba termasuk bakteri juga dapat memanfaatkan nitrat ini sebagai sumber $\mathrm{N}$ bagi kehidupannya.

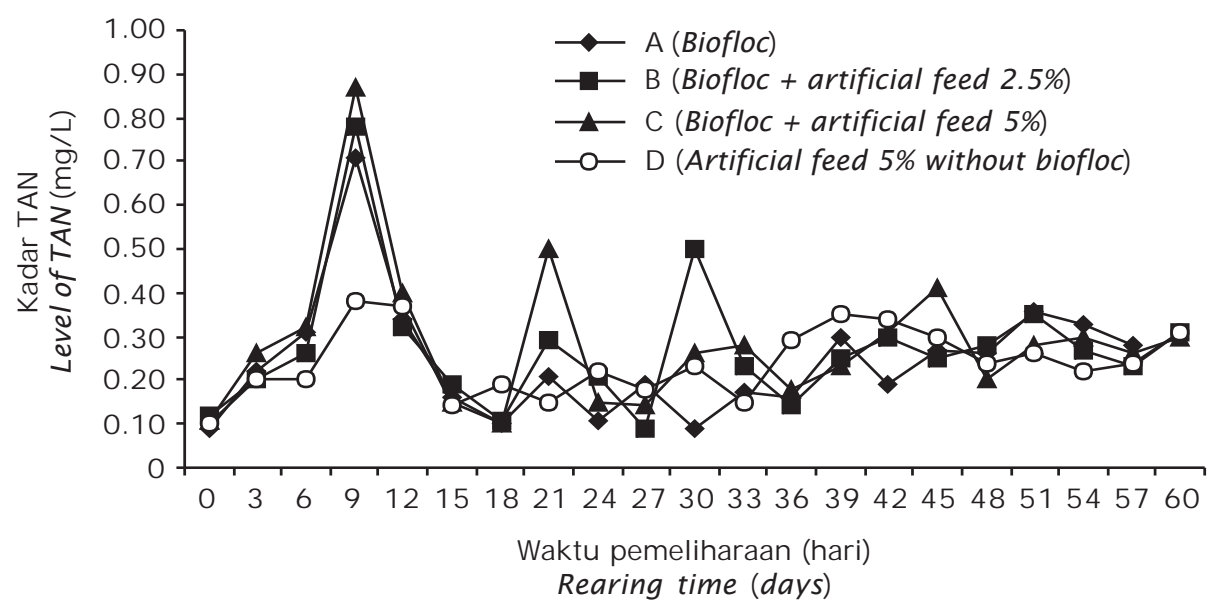

Gambar 1. Pola dinamika amonia nitrogen total (TAN) dalam media budidaya

Figure 1. Dynamic pattern of total ammonium nitrogen (TAN) in the rearing media 


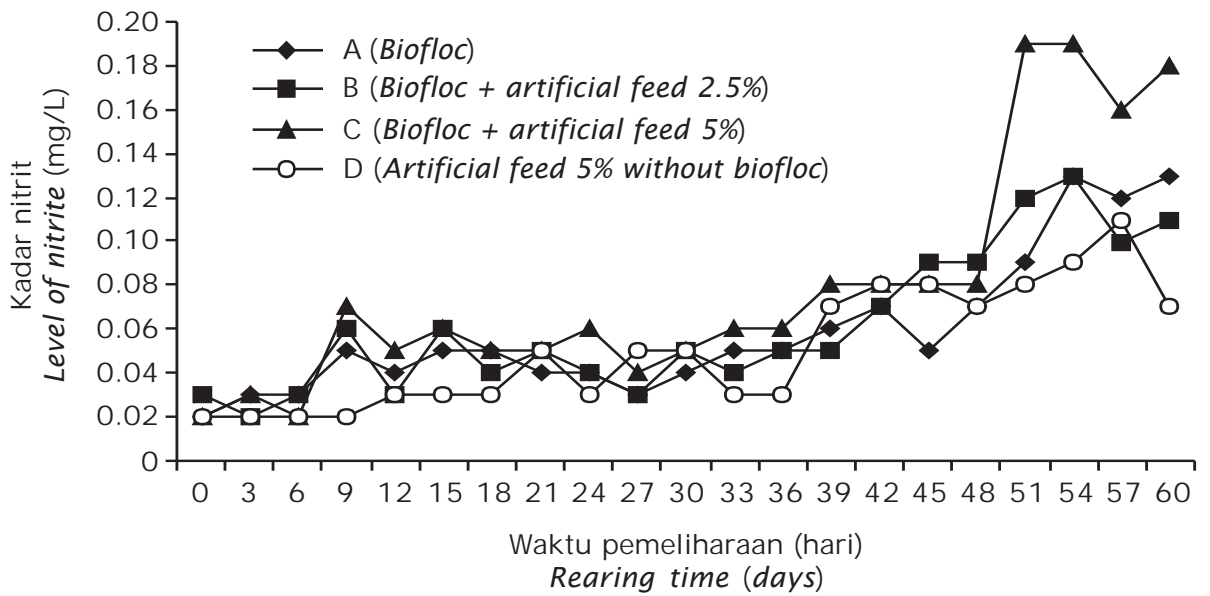

Gambar 2. Pola dinamika nitrit dalam media budidaya ikan bandeng

Figure 2. Dynamic pattern of nitrite $\left(\mathrm{NO}_{2}\right)$ in the milkfish rearing media

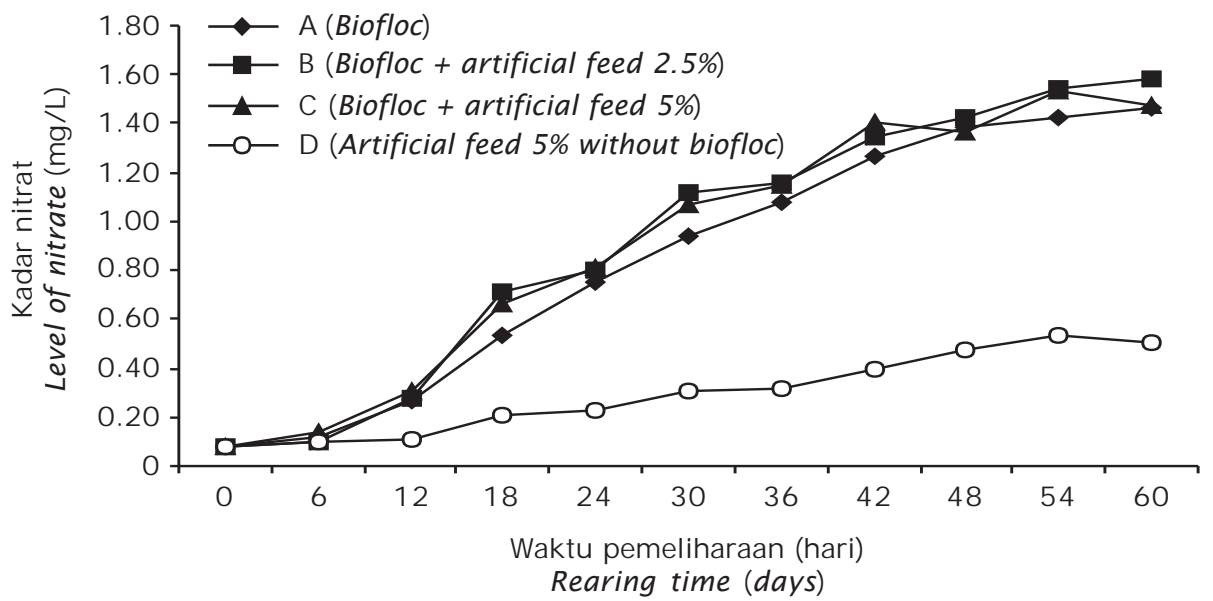

Gambar 3. Pola dinamika nitrat $\left(\mathrm{NO}_{3}\right)$ dalam media budidaya

Figure 3. Dynamic pattern of nitrate $\left(\mathrm{NO}_{3}\right)$ in the milk fish rearing media

\section{Oksigen Terlarut}

Oksigen terlarut dalam air merupakan faktor penting dalam proses penumbuhan bakteri heterotrof (bioflok). Dinamika oksigen terlarut pada awal, pertengahan, dan akhir penelitian disajikan pada Gambar 4. Pada gambar tersebut terlihat bahwa kandungan oksigen terlarut pada awal penelitian relatif cukup tinggi yaitu rata- rata masih di atas 5,0 $\mathrm{mg} / \mathrm{L}$. Namun kelarutan oksigen ini semakin menurun dengan semakin bertambahnya periode pemeliharaan pada budidaya teknologi bioflok. Hal ini disebabkan terjadinya pertumbuhan populasi bakteri yang membentuk bioflok. Peningkatan kuantitas bioflok ini terlihat pada peningkatan kandungan total suspended solid (TSS), volatile suspended solid (VSS), dan total bakteri heterotrof dalam media budidaya (Gambar 5, 6, dan 7).

\section{Produksi dan Karakterisitik Bioflok}

Gambaran produksi bioflok dapat dilihat pada perkembangan kandungan total suspended solid (TSS), volatile suspended solid (VSS), dan jumlah bakteri heterotrof dalam media budidaya. Kandungan TSS dan VSS 


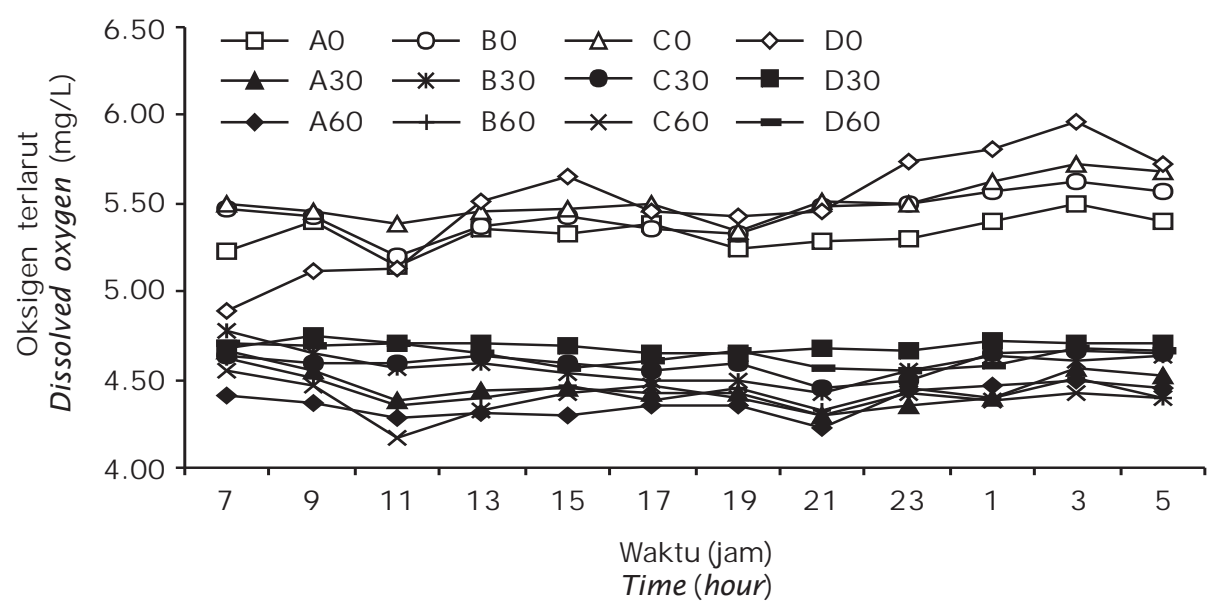

Gambar 4. Kandungan oksigen terlarut selama 24 jam pada awal (A0, B0, C0), 30 hari (A30, B30, C30), dan 60 hari (A60, B60, C60) penelitian dalam media budidaya ikan bandeng

Figure 4. Dissolved oxygen measured for 24 hours at the initial $(A O, B O, C O), 30^{\text {th }}$ day $(A 30, B 30, C 30)$, and $60^{\text {th }}$ day $(A 60, B 60, C 60)$ of rearing period

meningkat dengan meningkatnya periode pemeliharaan (Gambar 5 dan 6). Peningkatan kandungan TSS dan VSS ini terjadi karena konversi limbah $\mathrm{N}$ dari kegiatan budidaya ikan bandeng dan penambahan C-organik dari molase menjadi mikroorganisme heterotrof yang selanjutnya membentuk bioflok (Gambar 7). Bentuk dan ukuran bioflok yang terbentuk cukup beragam dengan ukuran berkisar antara 50- $1700 \mathrm{~mm}$.
Floc volume index (FVI) merupakan salah satu indikator untuk melihat laju endap VSS. Semakin rendah nilai FVI, maka semakin mudah flok itu mengendap. Pada penelitian ini, nilai floc volume index (FVI) berkisar antara 92- 188 $\mathrm{mL} / \mathrm{g}$ dengan nilai rata- rata $159 \pm 29 \mathrm{~mL} / \mathrm{g}$. Nilai indeks ini lebih rendah dibandingkan yang diperoleh Ekasari (2008) yaitu 519- 720 $\mathrm{mL} / \mathrm{g}$. Menurut De Schryver et al. (2008), FVI yang baik untuk akuakultur memiliki nilai $>200$

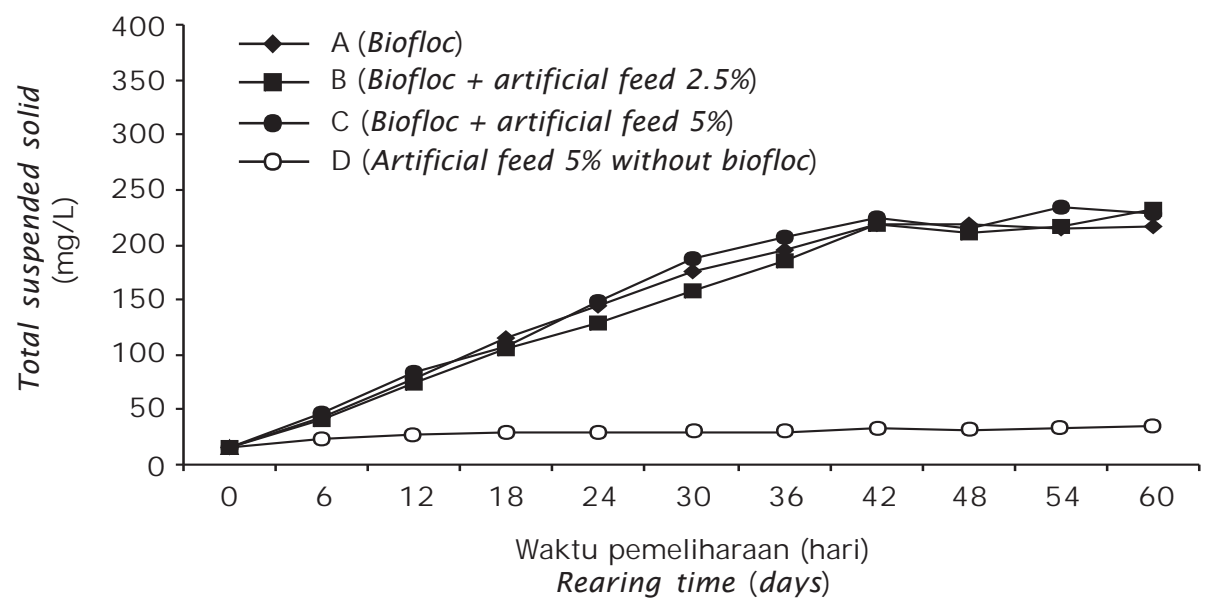

Gambar 5. Pola dinamika total suspended solid (TSS) dalam media budidaya ikan bandeng

Figure 5. Dynamic pattern of total suspended solid (TSS) in the milk fish rearing media 


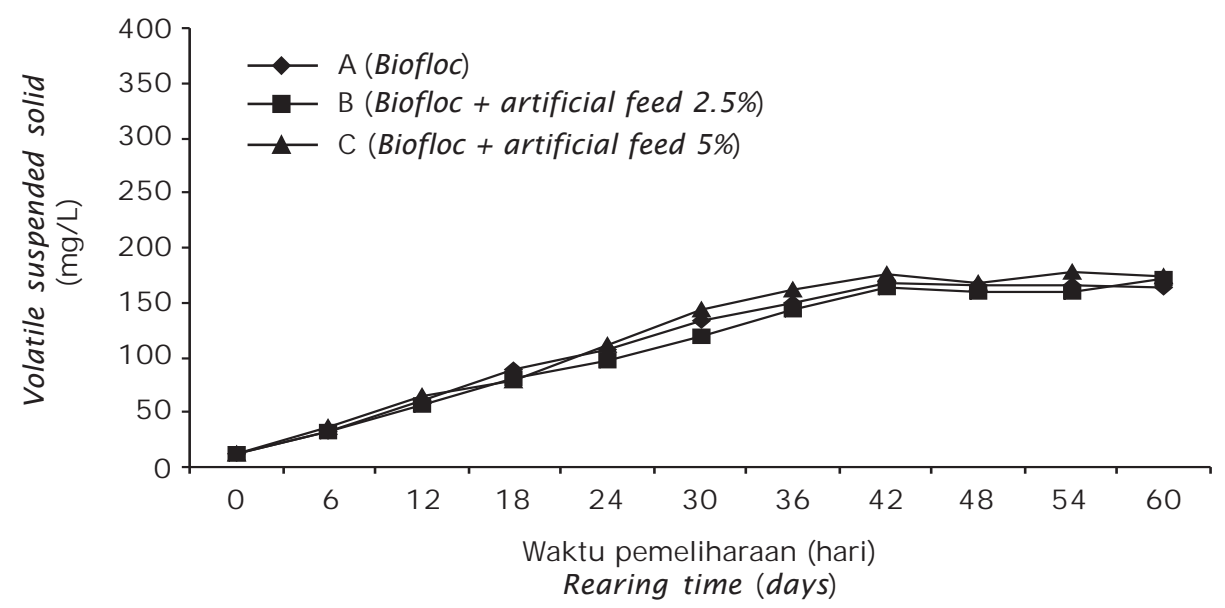

Gambar 6. Pola dinamika volatile suspended solid (VSS) dalam media budidaya ikan bandeng

Figure 6. Dynamic pattern of volatile suspended solid (VSS) in the milk fish rearing media
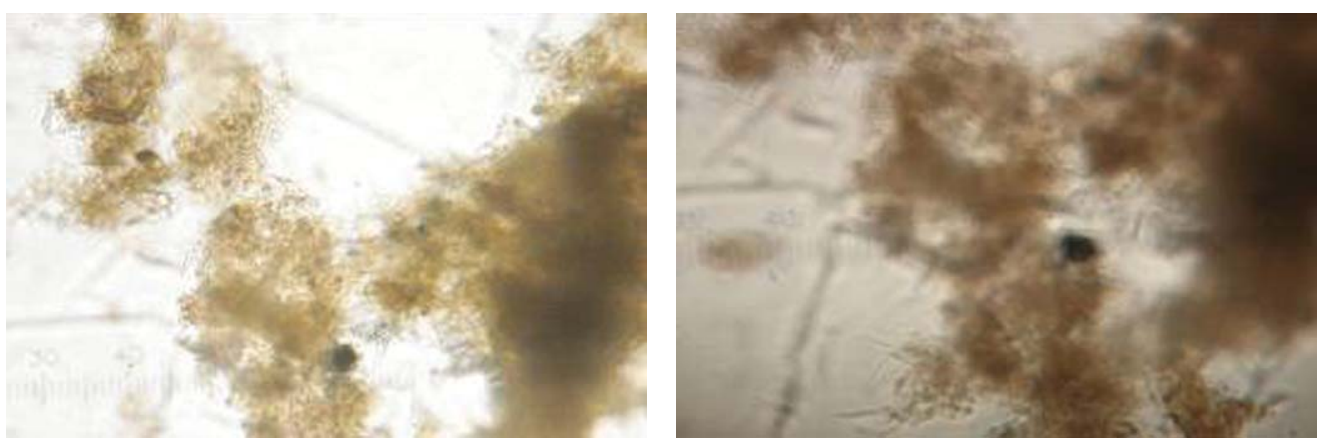

Gambar 7. Bioflok yang terbentuk dalam media budidaya ikan bandeng

Figure 7. Bioflocs formed in the rearing media of milk fish

$\mathrm{mL}$ g. Hal ini menunjukkan bahwa nilai FVI yang didapatkan pada penumbuhan bioflok ini masih lebih rendah daripada yang disarankan. Nilai FVI yang agak rendah pada penelitian ini disebabkan karena komponen penyusun bioflok tampak tidak banyak didominasi oleh bakteri filamentus. Akibat rendahnya nilai FVI, maka banyak bioflok yang telah terbentuk selanjutnya mengendap pada dasar bak. Untuk menghindari terjadinya pembusukan bioflok yang mengendap, maka dilakukan penyiponan secara berkala.

Bioflok merupakan campuran heterogen dari mikroba (bakteri, plankton, fungi, protozoa, ciliata, nematoda), partikel, koloid, polimer organik, kation yang saling berintegrasi cukup baik dalam air untuk tetap bertahan dari agitasi (goncangan) air yang moderat (Jorand et al., 1995). Pembentukan bioflok diinisiasi oleh bakteri heterotrof ketika mencapai suatu kepadatan populasi tertentu yang cukup tinggi. Pada awal penelitian, media budidaya penumbuhan bioflok (perlakuan A, B, dan C) diinokulasi dengan bakteri komersil berupa Bacillus sp. masing- masing sebanyak $1 \times 10^{6}$ $\mathrm{cfu} / \mathrm{mL}$, sehingga kepadatan populasi bakteri relatif tinggi pada perlakuan tersebut dibandingkan pada perlakuan D (kontrol, pergantian air setiap hari sekitar 30\%). Berdasarkan hasil pengamatan dinamika perkembangan populasi bakteri heterotrof dalam media budidaya (Gambar 8) tampak 


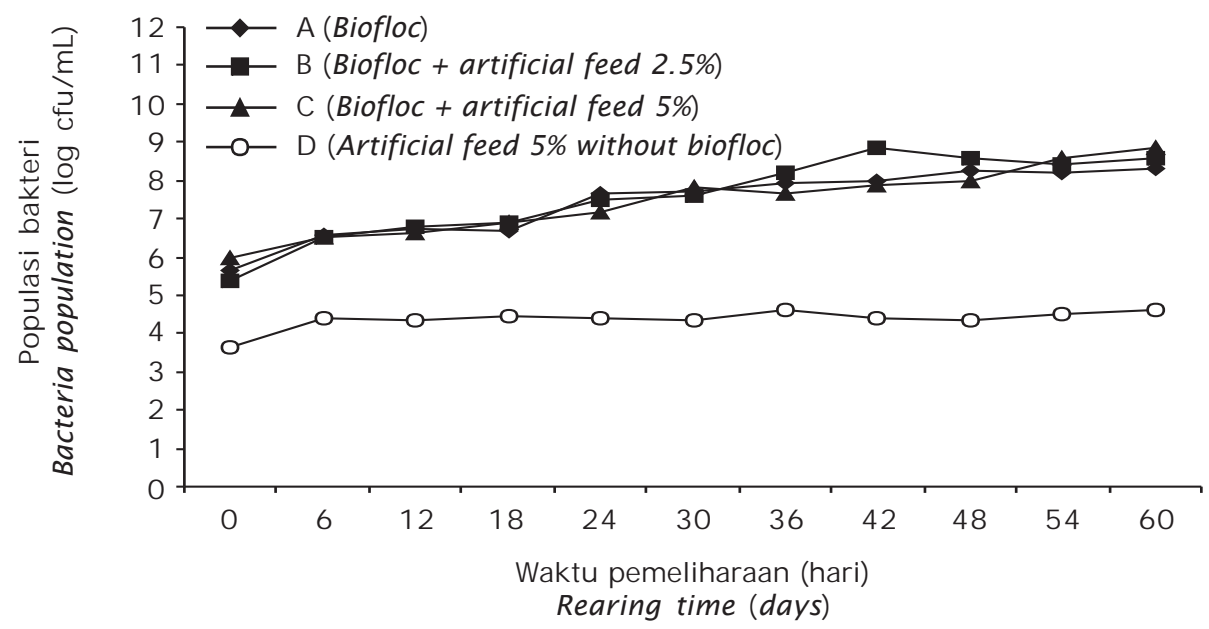

Gambar 8. Pola dinamika total bakteri dalam media budidaya ikan bandeng dengan teknologi bioflok

Figure 8. Dynamic pattern of total heterotroph bacteria in the rearing media

bahwa populasi bakteri pada perlakuan A, B, dan $C$ mengalami peningkatan dengan bertambahnya lama pemeliharaan. Populasi bakteri heterotrof pada media bioflok ini mencapai $10^{8} \mathrm{cfu} / \mathrm{mL}$, sementara pada media konvensional hanya berkisar $10^{4} \mathrm{cfu} / \mathrm{mL}$.

\section{Komposisi Nutrisi Bioflok}

Berdasarkan hasil analisis proksimat terhadap bioflok yang terbentuk (Tabel 3), didapatkan kandungan nutrisi yang relatif tidak berbeda nyata di antara perlakuan $(P>0,05)$.
Pada penelitian ini, bioflok ditumbuhkan dengan molase sebagai sumber $\mathrm{C}$ organik dan memiliki kandungan protein bioflok yang lebih rendah daripada bioflok yang ditumbuhkan dengan asetat $(42 \% \pm 8 \%$, glisero $(43 \%+1 \%)$, dan gliserol + Bacillus sp. $(58 \%+9 \%$, tetapi relatif sama dengan yang ditumbuhkan dengan glukosa (28\%+3\%) (Crab et al., 2009). Ballester et al. (2010), juga melaporkan nutrisi bioflok dengan kandungan protein 30,4\% lemak 4,7\% serat kasar 8,3\% dan abu 39,2\%yang ditumbuhkan menggunakan sumber C- organik molase dan

Tabel 3. Komposisi proksimat kandungan nutrisi bioflok yang tumbuh dalam media budidaya Table 3. Proximate composition of bioflocs (\% dry matter)

\begin{tabular}{|c|c|c|c|}
\hline \multirow[b]{2}{*}{$\begin{array}{c}\text { Nutrisi } \\
\text { Nutrient }\end{array}$} & \multicolumn{3}{|c|}{ Perlakuan (Treatments) } \\
\hline & $\begin{array}{c}\text { A. } \\
\text { Bioflok } \\
\text { Biofloc }\end{array}$ & $\begin{array}{c}\text { B. } \\
\text { Bioflok }+2.5 \% \text { pakan } \\
\text { (Biofloc }+ \text { feed } 2.5 \%)\end{array}$ & $\begin{array}{c}\text { C. } \\
\text { Bioflok }+5 \% \text { pakan } \\
\text { (Biofloc }+ \text { feed } 5 \% \text { ) }\end{array}$ \\
\hline Protein kasar (Crude protein) & $29.4 \pm 1.5^{\mathrm{a}}$ & $28.9 \pm 1.8^{a}$ & $30.1+1.6^{a}$ \\
\hline Lemak (Lipid) & $4.0 \pm 0.1^{a}$ & $3.8 \pm 0.6^{a}$ & $4.2 \pm 0.5^{\mathrm{a}}$ \\
\hline Serat kasar (Fibre) & $3.2 \pm 0.6^{\mathrm{a}}$ & $2.6 \pm 0.4^{a}$ & $2.7 \pm 0.5^{\mathrm{a}}$ \\
\hline Abu (Ash) & $27.3 \pm 2.0^{\mathrm{a}}$ & $26.2 \pm 2.1^{\mathrm{a}}$ & $25.7 \pm 4.7^{a}$ \\
\hline BETN (NFE) & $36.1 \pm 1.6^{a}$ & $38.8 \pm 4.0^{\mathrm{a}}$ & $37.3 \pm 4.9^{a}$ \\
\hline
\end{tabular}

Nilai tengah dalam baris yang sama diikuti superscript yang sama menunjukkan tidak berbeda nyata $(P>0,05)$ (Means in the same row followed by the same superscript are not significantly different) $(P>0.05)$ * BETN (Bahan Ekstrak Tanpa Nitrogen (Nitrogen free extract)) 
Tabel 4. Profil asam amino esensial bioflok dan badan ikan bandeng (\%protein)

Table 4. Essential amino acid profile of biofloc and whole body of milkfish (\% protein)

\begin{tabular}{lcc}
\hline $\begin{array}{c}\text { Jenis asam amino esensial } \\
\text { Kind of essential amino acid }\end{array}$ & $\begin{array}{c}\text { Bioflok } \\
\text { Biofloc }\end{array}$ & $\begin{array}{c}\text { Badan ikan bandeng } \\
\text { Whole body of milkfish }\end{array}$ \\
\hline Arginine & 3.99 & 7.5 \\
Histidine & 1.3 & 4.89 \\
Iso-leuc ine & 2.89 & 3.93 \\
Leucine & 4.28 & 7.33 \\
Lysine & 2.76 & 7.92 \\
Methionine & 1.43 & 3.72 \\
Phenilalanine & 3.06 & 4.24 \\
Threonine & 4.15 & 4.91 \\
Valine & 4.02 & 4.55 \\
Tryptophan & $\mathrm{ttd}$ & $\mathrm{ttd}$ \\
\hline
\end{tabular}

Keterangan (Note): $\mathrm{ttd}=$ tidak terdeteksi (undetected)

dedak gandung (wheat bran). Kandungan nutrisi khususnya protein bioflok ini relatif mendekati kandungan protein pakan buatan $(32,6 \%)$ yang digunakan dalam penelitian ini.

Selain kandungan protein kasarnya, komponen nutrisi pakan yang sangat penting peranannya dalam pertumbuhan ikan adalah profil asam amino pakan. Bioflok yang terbentuk dalam media budidaya ini memiliki profil asam amino esensial seperti disajikan pada Tabel 4. Pada tabel tersebut terlihat bahwa beberapa asam amino esensial dalam tepung bioflok memiliki kandungan yang cukup rendah dibandingkan kandungan asam amino dalam tubuh ikan bandeng, utamanya asam amino histidine, lysine, dan methionine. Rendahnya kandungan beberapa asam amino bioflok tersebut menyebabkan kurang seimbangnya dengan profil asam amino tubuh ikan bandeng. Hal ini akan menyebabkan kurang termanfaatnya protein bioflok untuk pertumbuhan ikan secara optimum karena asam amino yang rendah akan menjadi faktor pembatas, sehingga asam amino yang memiliki kandungan cukup tinggi akan dideaminasi menjadi sumber energi dan eskresi amonia akan meningkat (Saavedra et al., 2009). Berdasarkan hal tersebut, maka kemungkinan ini pula yang menyebabkan laju pertumbuhan ikan bandeng yang diberi bioflok sebagai makanan tunggal menjadi relatif rendah dibandingkan yang diberi pakan buatan.

\section{KESIMPULAN}

Berdasarkan hasil penelitian ini, maka disimpulkan bahwa:

- Ikan bandeng yang dipelihara dalam jaring sebagai penyuplai TAN untuk penumbuhan bioflok dalam media budidaya relatif tidak memanfaatkan bioflok sebagai makanan untuk pertumbuhannya.

- Ikan bandeng yang dipelihara di luar jaring masih dapat memanfaatkan bioflok untuk pertumbuhannya jika tidak diberikan pakan buatan atau diberi dalam jumlah yang tidak memadai (2,5\% hari), meskipun dengan laju pertumbuhan yang relatif rendah bila dibandingkan dengan ikan yang diberi pakan buatan $5 \%$ hari.

- Tanpa memperhitungkan jumlah pemberian molase dalam media budidaya, ikan yang diberi pakan buatan sebanyak 2,5\% hari dalam media bioflok, dapat meningkatkan efisiensi pakan sebanyak 58,5\% dan efisiensi pemanfaatan protein sebanyak $59,2 \%$ dibandingkan ikan yang diberi pakan $5 \%$ hari.

\section{DAFTAR ACUAN}

Ahmad, T., Priyono, A., Aslianti, T., Setiadharma, T., \& Kasprio. 1993. Pedoman teknis pembenihan ikan bandeng. Seri Pengembangan Hasil Penelitian Perikanan No.PHP/ KAN/24/ 
1993. Badan Penelitian dan Pengembangan Pertanian, $68 \mathrm{hlm}$.

APHA (American Public Health Association). 1995. Standard Methods for the Examination of Water and Waste Water, $19^{\text {th }}$ ed. American Public Health Association, Washington, DC, $1082 \mathrm{pp}$.

AOAC (Association of Official Analytical Chemists) International. 1999. Official Methods of Analysis, $16^{\text {th }}$ edn. Gaithersberg, Maryland, USA, $1141 \mathrm{pp}$.

Avnimelech, Y. 1999. Carbon/ nitrogen ratio as a control element in aquaculture systems. Aquaculture, 176: 227- 235.

Avnimelech, Y. 2007. Feeding with microbial flocs by tilapia in minimal discharge bioflocs technology ponds. Aquaculture, 264: 140- 147.

Bagarinao, T.U. 1994. Systematics, distribution, genetics and life history of milkfish, Chanos chanos. Environmental Biology of Fishes, 39: 23- 41.

Ballester, E.L.C., Abreu, P.C., Cavalli, R.O., Emerenciano, M., de Abreu, L., \& Wasielesky, W., J.R. 2010. Effect of practical diets with different protein levels on the performance of Farfantepenaeus paulensis juveniles nursed in a zero exchange suspended microbial flocs intensive system. Aquaculture Nutrition, 16: 163172

Burford, M.A, Thompson, P.J. ,Mclntosh, R.P., Bauman, R.H., \& Pearson, D.C. 2004. The contribution of flocsculated material to shrimp (Litopenaeus vannamei) nutrition in a high-intensity, zero exchange system. Aquaculture, 232: 525-537.

Crab, R., Chielens, B., Wille, M., Bossier, P., \& Verstraete, W. 2009. The effect of different carbon sources on the nutritional value of bioflocs, a feed for Macrobrachium rosembergii postlarvae. Aquaculture Research, p. 1-9.

De Schyver, P., Crab, R., Defoirdt, T., Boon, N., $\&$ Verstraete, W. 2008. The basics of bioflocss technology: The added value for aquaculture. Aquaculture, 277: 125- 137.

Ekasari, J. 2008. Bio-floc technology: The effect different carbon source, salinity and the addition of probiotics on the primary nutritional value of the bio-flocs. Thesis. Ghent University, Belgium, $72 \mathrm{pp}$.

Halver, J.E. \& Hardy, R.W. 2002. Nutrient flow and retention. In: Halver J.E. and R.W. Hardy.
(Eds.). Fish Nutrition. Academic Press, New York, p. 755- 770.

Hardy, R.W. 1989. Diet preparation. In Halver, J.E. (ed.). Fish Nutrition. Second Edition. Academic Press, Inc. San Diego, p. 476- 549.

Huisman, E.A. 1987. Principles of fish production. Department of Fish Culture and Fisheries, Wageningen Agricultural University, Wageningen, Netherlands, $170 \mathrm{pp}$.

Jorand, F., Zartarian, F., Thomas, F., Block, J.C., Betteru, J.V., Villemin, G., Urbain, V., \& Manen, J. 1995. Chemical and structural (2nd) linkage between bacteria within activated- sludge flock. Water Res, 29(7): 16391647.

Montoya, R. \& Velasco, M. 2000. Role of bacteria on nutritional and management strategies in aquaculture systems. Global Aquaculture Advocate, 3(2):35- 36.

Saaverdra, M., Pausao- Ferreira, P., Yufera, M., Dinis, M.T., \& Conceicao, L.E.C. 2009. A balanced amino acid diet improves Diplodus sargus larval quality and reduces nitrogen excretion. Aquaculture Nutrition, 15: $517-$ 529.

Schulz, C., Knaus, U., Wirth, M., \& Rennert, B. 2005. Effect of varying dietary fatty acid propile on growth performance, fatty acid, body and tissue composition of juvenile pike perch (Sander lucioperca). Aquaculture Nutrition, 11: 403- 413.

Schneider, O., Sereti, V., Eding, E.H., \& Verreth, J.A.J. 2005. Analysis of nutrient flows in integrated intensive aquaculture systems. Aquaculture Engineering, 32: 379-401.

Takeuchi, T. 1988. Laboratory work- chemical evaluation of dietary nutrients. In: Watanabe, T. (ed.) Fish Nutrition and Mariculture. JICA Kanagawa International Fisheries Training Centre, Tokyo, p. 179233.

Usman, Palinggi, N.N., Harris, E., Jusadi, D., Supriyono, E., \& Yuhana, M. 2010. Analisis tingkat kecernaan pakan dan limbah nitrogen $(\mathrm{N})$ budidaya ikan bandeng serta kebutuhan C- organik untuk penumbuhan bakteri heterotrof (bioflok). J. Ris. Akuakultur, 10(3): 481- 490.

Usman, Palinggi, N.N., Harris, E. , Jusadi, D., \& Yuhana, M. 2011. Pemanfaatan bioflok sebagai makanan pada beberapa ukuran ikan bandeng. Laporan Hasil Penelitian. Balai Riset Perikanan Budidaya Air Payau, 18 halaman (in press). 
Verstraete, W., Schryver, P.D., Defoirdt, T., \& Crab, R. 2008. Added value of microbial life in flock. Laboratory for Microbial Ecology and Technology, Ghent Univeristy, Belgium. 43p. http:/ / labmet.ugent.be, 43 pp.
Wilson, R.P. 2002. Amino acids and proteins. In: Halver J.E. and R.W. Hardy, (Eds.) Fish Nutrition. New York: Academic Press, p. 143- 179. 